\title{
CONCORDAT AND RESTRUCTURING IN TURKISH INSOLVENCY LAW (A REVIEW FROM ADR PERSPECTIVE)
}

\section{Mustafa GÖKSU*}

\begin{abstract}
All modern legal systems present alternatives to the ultimate and undesirable conclusion of bankruptcy liquidation for insolvent debtors. These alternatives provide reorganization and restructuring of unpaid debts, the debtor or even both. Even though there is a wide range of reorganization schemes throughout different legal systems, the essence of these mechanisms are surprisingly similar. They provide temporary protection for debtors who are in financial trouble with the hopes of a possible rescue, while incorporating the creditors in the process. The key point of all these schemes is almost always the concession to be made by both sides. This aspect of reorganization mechanisms is unmistakably reminiscent of amicable resolution of conflicts and alternative dispute resolution, even though the origins of the reorganization mechanisms mostly lack this perspective. In this article, concordat and restructuring in Turkish law and the aforementioned similarity and a possible relation between these institutions and ADR are examined.
\end{abstract}

Keywords: Bankruptcy, reorganization, insolvency, concordat, alternative dispute resolution

\section{TÜRK KÜLLI ICRA HUKUKUNDA KONKORDATO VE YENIDEN YAPILANDIRMA (ALTERNATIF UYUŞMAZLIK ÇÖZÜMÜ PERSPEKTIFINDEN BIR INNCELEME)}

\section{$\ddot{O} Z$}

Tüm modern hukuk sistemleri, ödeme güçlüğ̈̈ içine düşen borçlulara, istenmeyen bir sonuç olan iflas tasfiyesine karşı alternatifler sunmaktadırlar. Bu alternatifler borçların, borçlunun veya bazen de her ikisinin birlikte yeniden yapılandırılmasını mümkün kllarlar. Her ne kadar farklı hukuk sistemlerinde çok çeşitli mekanizmalara

\footnotetext{
Asst. Prof. Dr., Civil Procedure, Compulsory Enforcement and Bankruptcy Law Department, Ankara Hacı Bayram Veli University, Faculty of Law.

Email: mustafa.goksu@hbv.edu.tr

ORCID ID: 0000-0003-3414-1699

DOI : 10.34246/ahbvuhfd. 813023
Yayın Kuruluna Ulaştığı Tarih : 23/09/2020

Yayınlanmasının Uygun Görüldüğü Tarih: 08/10/2020
} 
rastlansa da, bu yolların özlerinde şaşırtıcı şekilde benzer oldukları kolaylikla görülebilir. Tüm bu yollar, bir taraftan borçluya yeniden ayağa kalkabilmesi için bir koruma sağlarken, diğer taraftan da alacakllları prosedüre dâhil etmektedirler. Bu yolların kilit noktasını, çoğunlukla her iki tarafça verilen ödünler oluşturmaktadır. Yeniden yapılandırma kurumlarının çılkıs noktaları ve varoluş amaçları farklı temellere dayansa da kurumların bu boyutu, anlaşmazlıkların dostane yollarla çözümü ve alternatif uyuşmazlık çözümü kurumları ile büyük ölçüde benzerlik göstermektedir. Bu makalede, Türk hukukundaki konkordato ve yeniden yapllandirma kurumlart ve bu kurumlar ile alternatif uyuşmazlık çözüm yolları arasındaki benzerlik ve muhtemel iliş̧ki incelenmişstir.

Anahtar Kelimeler: Iflas, yeniden yapılandırma, ödeme güçlügü̈, konkordato, alternatif uyuşmazllk çözümü

\section{INTRODUCTION: AN OVERVIEW OF TURKISH INSOLVENCY LAW}

In general, compulsory debt enforcement and insolvency law are considered as parts of a common legal subject in Turkey. This is also evident in the title of the principle legislation regulating almost all aspects of the partial (debt collection) and collective (bankruptcy and reorganization) enforcement procedures, the Code of Compulsory Enforcement and Bankruptcy (numbered 2004), which was enacted in 1932. Since the Code is a relatively old piece of legislation, it must be noted that it received numerous amendments through the years. An effort is under way to enact a completely new statute while maintaining same major principles of the current Code. As it will be examined later, one can easily say the rehabilitative aspect of insolvency law is somewhat an afterthought in the Code. Even the name of the Code contains the term bankruptcy, rather than insolvency. Bankruptcy in Turkish, which is iflas, refers to the liquidation solution to the insolvency problem. This solution along with the rarely used concordat, carried on for many years until more modern mechanisms were introduced in 2003. However, these mechanisms were also amended or some even completely vacated in the following years.

Currently, there are three major mechanisms regarding the dissolution of insolvencies: Bankruptcy (liquidation), concordat and restructuring of corporations and cooperatives via reconciliation.

Bankruptcy is the main (at least with regard to the soul of the Code) and the ultimate way to dissolve insolvency. Bankruptcy, within the context 
of Turkish law, represents the liquidation of the debtor's assets. However, it must be expressly indicated that, bankruptcy within the Code of Compulsory Enforcement and Bankruptcy (CCEB), is not limited to insolvency. Since the compulsory enforcement and bankruptcy is tightly linked in theory and in practice, a debtor eligible for bankruptcy may be bankrupted also on the basis of a defaulted money payment ${ }^{1}$. According to the CCEB, should the debtor fail to pay a monetary debt, the creditor may either seek seizure/attachment of the debtor's assets or request a judgment of bankruptcy from the court provided that the debtor is eligible for bankruptcy ${ }^{2}$. Eligibility for bankruptcy is determined by the CCEB and the Commercial Code (no. 6012). In general, merchants are eligible for bankruptcy; however there are some exceptions to this rule ${ }^{3}$. In summary, according to Turkish law, entire assets of a billiondollar company may be liquidated on account of a miniscule monetary debt ${ }^{4}$.

The other aspect of the bankruptcy is of course dependant on the insolvency status of the debtor. We are using the insolvency term broadly here, since there are many grounds for direct bankruptcy according to the CCEB (art. 177-179). If a debtor becomes insolvent and cannot see a way out or there really is no other option; she or a creditor of hers may apply for bankruptcy. Bankruptcy occurs with the judgment of the commercial court in the place of business of the debtor (art. 154). After the judgment, an automatic stay regarding all compulsory enforcement procedures (barring some exceptions) against the debtor commences and liquidation proceedings begin (art. 193). Liquidation proceedings start with the bankruptcy agency, which is a governmental one. However, following the first meeting of the creditors, a board of trustees are selected by the creditors and appointed by the

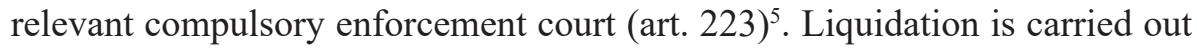
by the board within the strict rules of the CCEB and the instructions given by the creditors in their second meeting or consecutive meetings if any.

KURU, pp. 1102-1103; ARSLAN / YILMAZ / TASSPINAR- AYVAZ / HANAĞASI, p. 443; PEKCANITEZ / ATALAY / SUNGURTEKIN ÖZKAN / ÖZEKES, p. 628; ATALI / ERMENEK / ERDOĞAN, p. 522.

2 It must be noted that bankruptcy route is not mandatory for merchants; it is the creditor's choice. (KURU, p. 172; PEKCANITEZ / ATALAY / SUNGURTEKIN ÖZKAN / ÖZEKES, pp. 630-631)

3 UZAR SCHÜLLER, p. 42-15.

4 For an examination on this notion see YEŞİLOVA, pp. 142-147.

5 UZAR SCHÜLLER, p. 42-20. 
The board liquidates the estate of the debtor (now "the bankrupt / müflis") and designates all credits owed by her. If any disputes arise regarding these credits, they are resolved by relevant courts or of course by amicable resolution. After all is done, the board pays the creditors what they are owed according to the distribution priorities determined by the CCEB (art. 206); and gives a final report to the commercial court, which then finalizes the liquidation process (art. 254). A crucial aspect of bankruptcy in Turkish law is the absence of the "clean-page / fresh-start" concept. The debtor is not resolved of her debts just because she had gotten through the bankruptcy proceedings. If any debt remains even partially unpaid, the board drafts a document which is aptly named "insolvency certificate - borç ödemeden aciz belgesi" and issues it to the unpaid creditor (art. 251). With this document, the creditor may pursue compulsory enforcement in the future provided that the debtor had obtained new assets.

Since bankruptcy results in the complete liquidation of the assets of the debtor as it is summarized above, it is almost impossible to find any similarities between this proceeding and ADR. Maybe the only aspect of bankruptcy involving another party is creditors' limited participation in liquidation proceedings; and also their authority to settle debts/credits of the debtor via the creditors committee's second meeting (art. 237-238). Therefore, bankruptcy will be excluded from the final chapter and also the title of this article.

The other two mechanisms for fending off insolvency are composition agreements with debtors or concordat as it will be called in this article; and restructuring of corporations and cooperatives via reconciliation. Concordat is also comprised of three distinct proceedings. Another mechanism, postponement of bankruptcy, used to exist however it was abolished in 2018. All these mechanisms will be examined in the following chapters.

\section{CHAPTER I: A BRIEF HISTORY OF LIQUIDATION AND REORGANIZATION MECHANISMS IN TURKISH INSOLVENCY LAW}

\section{THE ORIGINAL TWO: BANKRUPTCY (LIQUIDATION) AND (SIMPLE) CONCORDAT}

The first legislation combining the compulsory enforcement and bankruptcy procedures in the Republic of Turkey was enacted in 1929 (numbered 1424). Before that, compulsory enforcement and bankruptcy 
procedures were regulated by different statutes. 1929 Code was adopted from the Swiss Federal Statute on Debt Enforcement and Bankruptcy (SchKG) mostly unchanged ${ }^{6}$. Bankruptcy (liquidation) and two types of simple concordat, namely ordinary (preventive) concordat and concordat in bankruptcy were present in this statute. Both mechanisms in Turkish legal history law date back to $19^{\text {th }}$ century under Ottoman law ${ }^{7}$. However, the eligibility was different under Ottoman law for both institutions. Unlike today, concordat was limited to merchants ${ }^{8}$. Furthermore, Mecelle (the Civil Code at the time) had provided some provisions regarding the bankruptcy for individuals; however it was abolished by the 1926 Turkish Civil Code?

After only three years in effect, the "incompatibility" of the 1929 Code to the "realities" of the Turkish life as well as the effects of the Great Depression led to the draft of the current Code in $1932^{10}$. The current Code of Compulsory Enforcement and Bankruptcy (CCEB) stands as a largely amended version of the 1929 Code. Insolvency mechanisms stated above were carried to the new Code mostly unchanged.

Both bankruptcy and concordat provisions in the Code were amended numerous times in the following years. However, the basis of these mechanisms mostly remained unaltered. Amendments were generally aimed at either expediting the processes or to prevent misuses emerged in practice apart from the reforms that will be examined below. Latest major amendment was in 2018 (Statute numbered 7101), and it overhauled the concordat provisions mostly to fill the gap left with the repeal of postponement of bankruptcy, which will be examined shortly.

Even though concordat will be examined in the next chapter, the raison d'être of the institution should be stated with regard to the only other option during that era, namely bankruptcy. Unlike bankruptcy, which does not absolve the debtor of her unpaid debts at the end of the procedure, concordat aims for the opposite. If a debtor chooses the concordat route and persuades the creditors (or at least the minimum required) as well as the court, she rids herself all of her debts, provided that she performs the stipulations of the composition

\footnotetext{
6 UMAR, p. 137; UZAR, pp. 42-43, 47.

7 UMAR, p. 87; UZAR, p. 27-28.

8 Ibid.

9 UMAR, p. 88.

10 ÜSTÜNDAĞ, pp.15-21; UZAR, p. 47, 51.
} 
agreement ${ }^{11}$. Therefore, it is a true reorganization method to absolve a debtor from her debts. Unfortunately, concordat could never be a popular means for this purpose in Turkey. The number of successful concordats was severely limited during this era.

\section{THE 2003 REFORM: 4949}

\section{A. In general}

In 2003, the CCEB was amended by the Statute numbered 4949. This amendment constitutes the second largest amendment in the Code's history ${ }^{12}$. It was and still is one of the most important amendments with regard to the topic of this study. Along with amending the rules of the existing proceedings, the amendment introduced two new mechanisms to Turkish insolvency law: Postponement of bankruptcy and concordat by way of cession of assets. The preamble of the amending Statute explicitly refers to the need to the reconstruction/reorganization mechanisms in order for the assets of the debtor to be protected, even improved in value ${ }^{13}$. It is also stated in the preamble that a delicate balance is ought to be achieved between liquidation and reconstruction.

\section{B. Postponement of Bankruptcy}

Even though the 2003 amendment introduced postponement of bankruptcy provisions to the CCEB, it must be noted that at the time, postponement of bankruptcy was already in effect in Turkish law, thanks to the then in effect Turkish Commercial Code of 1956 as well as the Law on Cooperations of 1969. However, these provisions were seldom utilized due to numerous reasons ${ }^{14}$. The CCEB, with the amended article 179 and newly added articles 179/a and 170/b, regulated the subject for nearly fifteen years.

Postponement of bankruptcy was a special means to prevent bankruptcy, namely liquidation. It was only available to corporations ${ }^{15}$ and cooperatives

11 POSTACIOĞLU, p. 12; BERKIN, p. 348.

12 The largest amendment was made in 1965 with the Statute numbered 538.

13 p. 2, https://www2.tbmm.gov.tr/d22/1/1-0550.pdf (Last accessed: 24.06.2020)

14 ERMENEK, p. 93.

15 Corporations in Turkish law are comprised of joint stock companies, limited liability companies and commandite companies limited by shares. Other types of companies in which partners are more important than the capital are excluded from this term. (AYHAN / ÇAĞLAR / ÖZDAMAR, pp. 9-10) 
under certain circumstances. If a corporation or cooperative's assets were unable to match its debts, this was and as a matter of fact still is grounds for direct bankruptcy (art. 179). Application for bankruptcy in this case is even mandatory for the responsible officers of the corporation. However, if the debtor could come up with a suitable proposal, it could secure a very favorable postponement. Postponement was a provisional relief for the debtor ${ }^{16}$. It aimed the protection of the debtor (corporation or cooperative) for a period of time in which it could, at least in theory, pick itself up and be able to pay its debts. Therefore, it was neither reconstruction of the corporation nor the reorganization of its debts on its own; it was a provisional relief aimed at the protection of the company from its creditors ${ }^{17}$.

The procedure used to begin with a request from the commercial court. This request had both involved direct bankruptcy and its postponement. The reason behind this was that postponement was available only if the bankruptcy conditions had been met $^{18}$. The debtor was obliged to provide any relevant documents, balance sheets and most importantly the proposal itself. The court had examined the request on its own initiative; i.e. it utilized ex officio investigation principle ${ }^{19}$. The court had appointed a trustee as well as taking any necessary measures to protect the assets of the debtor. The power of the trustee was not explicitly specified by the Code, it was determined by the court. If the conditions were met, the court could grant a postponement no longer than one year. However, the court had the authority to extend this period to a total of five years provided that the conditions were met.

The main consequence of the postponement was of course the stay and/ or prevention of any compulsory enforcement procedure against the debtor during the postponement. This stay was automatic once the postponement judgment was rendered. However, there were some credits exempt from this stay such as some labor credits and credits secured with property; but even these exemptions were limited. Barring the exceptions, no creditor could pursue the debtor in enforcement within the postponement period. If the rescue attempt was unsuccessful at the end of the postponement period or if the court

16 PEKCANITEZ / ATALAY / SUNGURTEKIN ÖZKAN / ÖZEKES, pp. 665. For a comprehensive examination on the legal characteristic of the institution see ERMENEK, pp. 106-128.

17 TAŞPINAR AYVAZ, p. 263; YARICI, pp. 188-189.

18 ERMENEK, p. 200.

19 PEKCANITEZ / ATALAY / SUNGURTEKIN ÖZKAN / ÖZEKES, p. 679. 
had denied the postponement in the first place, the court was obliged to render a judgment for bankruptcy. Therefore, the postponement period could have ended either with the desired result or badly.

As it was summarized above, the main two characteristics of the postponement of bankruptcy were its improperly long duration and the lack of any input from the creditors. Therefore, it was open for misuse in practice. The debtors could easily manufacture balance sheets and documents to persuade the court and fend off debtors for up to five long years. Due to its failure in effectiveness and rampant misuse, important amendments were enacted in 2016 with the Statute numbered 6728 to address its major issues. This amendment was aimed at generally making the procedure more difficult to misuse, as well as limiting the total postponement period to only two years. However, also in 2016, the use of postponement of bankruptcy provisions were halted by the Statutory Decrees numbered 669 and 673 through the state of emergency period, which lasted until 2018. Finally the Statute numbered 7101, which was enacted in the same year, abolished the postponement procedure entirely. The preamble of said Statute summarizes the principle changes brought by the Statute as the repeal of the "problem-ridden" postponement of bankruptcy procedure and the restoration of concordat as an efficient and functional procedure ${ }^{20}$.

\section{Concordat by way of Cession of Assets}

The 4949 introduced another "modern" method to fend off insolvency entitled concordat by way of cession of assets. This procedure was known in Switzerland and it was in the Swiss Federal Statute on Debt Enforcement and Bankruptcy (SchKG), which was the source Code to the CCEB, since $1949^{21}$. Since it will be examined in the following chapter, we will shortly mention here. Concordat by way of cession of assets is a true hybrid mechanism containing various aspects of both bankruptcy and ordinary concordat ${ }^{22}$. While the commencement, approval and the end result of the procedure (clean-page / fresh-start) resemble ordinary concordat; the part in-between, namely the liquidation of the assets, is akin to bankruptcy liquidation. The main difference between concordat by way of cession of assets and bankruptcy liquidation is that, liquidation is carried out directly by the creditors with broad authority

\footnotetext{
20 p. 19, https://www2.tbmm.gov.tr/d26/1/1-0913.pdf (Last accessed: 24.06.2020).

$21 \quad$ POSTACIOĞLU, p. 158.

22 KURU, p. 1542; ATALI / ERMENEK / ERDOĞAN, pp. 713-714.
} 
in the former, unlike the latter ${ }^{23}$. Moreover, although the name suggests the cession of "assets", it must be noted that, the power of disposition over the estate, not the assets themselves, are transferred to the creditors ${ }^{24}$.

\section{THE 2004 ADDITION: RESTRUCTURING OF CORPORATIONS AND COOPERATIVES VIA RECONCILIATION}

Before the 2004 Statute, there were two pieces of legislation aimed at protecting and rescuing financially distressed companies from going under in Turkish law. These were the Statute numbered 3332 (known as the Company Relief Law in short) which was enacted in 1987 and the Statute numbered 4743 (known as the İstanbul Approach) which was enacted in 2002 after the 2001 financial crisis ${ }^{25}$. Although both of these statutes were aimed at strengthening and protecting thereby rescuing financially distressed companies from going under, they had offered only unofficial out-of-court solutions. And thus both had failed to fulfill their purpose. İstanbul approach provides a template for a framework agreement between the debtor and creditors to negotiate for complicated restructuring ${ }^{26}$. However, as it is mentioned, this agreement fails to bear legal consequences with regard to the CCEB. Therefore, it is based completely on the principle of voluntariness ${ }^{27}$.

After the 4949 reform and the overhaul of concordat and introduction of the postponement of bankruptcy, the government had proposed a bill to the Parliament within the spirit of İstanbul Approach to save corporations from bankruptcy. The Statute was enacted in 2004 and introduced restructuring of corporations and cooperatives via reconciliation to the CCEB. This restructuring scheme is not dissimilar to concordat as it will be examined in the next chapter. However it must be noted that, unlike concordat which is available to any financially distressed debtor, restructuring is limited to corporations and cooperatives as the name suggests.

\section{THE 2018 SHAKE-UP: 7101}

The main impact of the Statute numbered 7101, as we have discussed above, was the complete removal of the postponement of bankruptcy

\footnotetext{
23 ARSLAN / YILMAZ / TAŞPINAR AYVAZ / HANAĞASI, p. 568.

24 TAŞPINAR AYVAZ, pp. 255-256; ATALI / ERMENEK / ERDOĞAN, pp. 713-714.

25 ULUC / SUTTON / YAVASI, p. 67.

26 TAŞPINAR AYVAZ, p. 221.

27 Ibid, p. 235.
} 
procedure. It not only repealed the relevant articles in the CCEB, but also all the references made within the Turkish Commercial Code and the Cooperatives Law. The Statute also overhauled the proceedings in ordinary concordat in order to make the process more feasible and attractive since it would de facto replace the then popular yet defunct postponement of bankruptcy. The Statute also made an addition to the concordat process: Negotiation with secured creditors and structuring of credits. This provision, for the first time in Turkish insolvency law history, introduced a type of binding reorganization procedure involving secured creditors. This procedure will be examined further, along with other mechanisms in reorganization.

\section{CHAPTER II: AN OVERVIEW OF CONCORDAT AND RESTRUCTURING IN TURKISH INSOLVENCY LAW}

\section{CONCORDAT IN GENERAL}

Concordat, under Turkish law is not fundamentally different than any other reorganization mechanism utilized throughout the world. It is similar in essence to the Nachlassvertrag or Insolvenzplan in Europe, to Chapter 11 reorganization in USA and the somewhat complicated administration / scheme of arrangement / voluntary arrangement procedures in England. All these procedures can easily be traced back to similar roots: The need for the debtor to be left standing, reorganization of debts and involvement (saying) of the creditors. The minor differences seem to be realized with regard to who can apply, what the prerequisites are, how the stay/moratorium works, how it can be challenged, etc. This difference in naming but similarity in substance is reminiscent of the ADR methods utilized throughout the world. A negotiation between the parties involving a neutral third party can easily be named mediation, conciliation or any other name depending on the jurisdiction or the legislation.

As it is mentioned above, concordat is not a new institution in Turkish law. Its roots date back to Roman law in genera ${ }^{28}$ and to the $19^{\text {th }}$ century for Turkish law; and it has been a staple of Turkish insolvency law, at least on paper, since early $20^{\text {th }}$ century ${ }^{29}$. Concordat ${ }^{30}$ is usually defined as a compulsory

\footnotetext{
28 The notion that "if the majority of the creditors agree to a continuance then it becomes mandatory for the dissenting creditors" dates back to Justinian. (VĖLYVIS / MIKUCKIENĖP, p. 294)

29 PEKCANITEZ / ERDÖNMEZ, pp. 3-4; ÖZTEK / BUDAK / TUNÇ YÜCEL / KALE / YEŞILOVA p. 31.

30 For the etymology of the word "concordat", see UMAR, p. 20, fn. 51.
} 
enforcement instrument allowing a debtor who is unable to pay her due debts to repair her financial standing by reaching an agreement with her creditors under the supervision and control of the court under conditions stipulated by the statute ${ }^{31}$. This "compulsory enforcement instrument" argument constitutes the dominant argument in Turkish legal literature ${ }^{32}$. Among other arguments regarding the legal characteristic of concordat, settlement (contract) between the debtor and creditors should also be mentioned. This somewhat old argument opines that concordat represents a settlement agreement between the debtor and her creditors regarding the unpaid debts ${ }^{33} .1850$ Commercial Code of the Ottoman Empire had introduced modern concordat as a compulsory settlement - cebri sulh between the debtor in bankruptcy and her creditors with no less that $30 \%$ percent approval of her creditors ${ }^{34}$.

Concordat provisions in the CCEB were amended numerous times throughout the almost century-old history of the Statute. These amendments were mostly introduced to make concordat more efficient and functional, thereby rendering it more appealing. However one can easily say that, concordat was never a popular tool in practice. The "agreement" aspect of the instrument may also be blamed, since the same can easily be said for the utilization of ADR in Turkey. However, since the repeal of the postponement of bankruptcy and the further push for the concordat by the Government demonstrated an uptick since 2018; but it may require years to see a complete picture as it was (and still is) the case with mediation statistics.

Before getting to the examination of the types of concordat under the CCEB, it must be noted that, a debtor and one or more of her creditors may also sign an out-of-court agreement regarding the standing debt ${ }^{35}$. This agreement becomes a law of obligations agreement and it is treated as such. This agreement lacks any direct result with regard to compulsory enforcement.

31 POSTACIOĞLU, p. 12; TANRIVER (Komiser), p. 3; ANSAY, p. 337; GÜRDOĞAN, p. 155; UMAR, p. 20; KURU, p. 1444; ÖZTEK (Öztek-Konkordato Şerhi), m. 285, no 9.

32 For the arguments on the subject, see UMAR, p. 21-27; TANRIVER, pp. 6-7; BERKIN, p. 348; POSTACIOĞLU, pp. 13-14; GÜRDOĞAN, pp. 155-156; PEKCANITEZ / ERDÖNMEZ, pp. 4-5.

33 However, this argument is justly criticized on grounds that it fails to explain the compulsoriness of the concordat for the dissenting creditors. An agreement cannot be imposed on a disagreeing party by definition. See Ibid.

34 UZAR, p. 28.

35 BERKIN, p. 350; ÖZTEK (Öztek-Konkordato Şerhi), m. 285, no 1; ATALI / ERMENEK / ERDOĞAN, pp. 633. 
However, if said agreement is made through mediation or conciliation with the involvement of both parties' lawyers, it becomes an enforceable instrument under the Law on Mediation in Civil Disputes and the Law of Lawyers respectively. However it is still not possible for it to be referred to as a concordat agreement within the context of the $\mathrm{CCEB}^{36}$.

\section{ORDINARY (PREVENTIVE) CONCORDAT}

As it was explained above, the CCEB provides three types of concordat: Ordinary concordat, concordat in bankruptcy and concordat by way of cession of assets. Ordinary (or preventive) concordat, as the name suggests, is the main type of concordat. It is similar to American Chapter 11 reorganization in most aspects. It involves a debtor who is in financial trouble and is unable to pay her due debts (illiquidity). A plausible probability in the future for said financial trouble (imminent illiquidity) is also sufficient grounds. The debtor is not required to be eligible for bankruptcy. If said debtor applies to the court, passes through all stages stipulated by the Code, persuades her minimum required number of creditors and gets her proposal confirmed by the court, an opportunity is created for her to clear said financial trouble and to be rescued from becoming bankrupt. The contents of any ordinary concordat are limited to a reduction in credit, continuance or both. Another type of agreement cannot be reached in ordinary concordat ${ }^{37}$.

\section{A. Commencement and Proposal}

The procedure starts with the request of the debtor from the commercial court (art. 285). The petitioning debtor must also enclose the proposal. Proposal may contain a reduction in payment, continuance for payment or both. The debtor cannot create any creditor classes within the proposal. All unsecured creditors that will be affected by the concordat constitute a single class ${ }^{38}$. There are no separate classes for investors/shareholders. The proposal cannot contain different provisions between the debtor and a particular creditor; the equality principle must be complied with ${ }^{39}$. The debtor is also obliged to present all relevant documents stipulated in the Code (art. 286) to the court, including an independent audit report. If a creditor aims to request concordat for her

\footnotetext{
36 Ibid.

37 PEKCANITEZ / ATALAY / SUNGURTEKIN ÖZKAN / ÖZEKES, pp. 776-777.

38 For adverse opinion see ATALAY, pp. 124-125.

39 ÖZTEK (Öztek-Konkordato Şerhi), m. 299, no 20.
} 
debtor (involuntary petition), the creditor must have the legal interest to file for bankruptcy for said debtor (art. 285). Once the court determines that all documents are presented, it grants a provisional period order (art. 287). This provisional period marks the commencement of the stay (moratorium) period for the protection of the debtor. Therefore, unlike the Chapter 11 procedure, the request (petition) itself does not grant the debtor an automatic stay, even though the preamble of the amendment makes a reference to Chapter 11's automatic stay provisions ${ }^{40}$. However, since the discretionary power of the court at this stage is severely limited ${ }^{41}$, the end results stand largely similar.

With the grant of the provisional period, the court also appoints a commissioner (or three depending on the circumstances) (art. 287). This commissioner aids the debtor for the refinement of the proposal, oversees the debtor's business activities, drafts necessary reports to the court and informs the creditors and the creditors committee. After the announcement of the provisional period, creditors may object to the concordat request before the court (art. 288). After the court hears all relevant parties and the provisional commissioner, it grants a one-year stay (final) period to the debtor, if it determines that the plan could succeed (art. 289). The court makes this decision upon examination on its own initiative; i.e. it utilizes ex officio investigation principle ${ }^{42}$. This period may be extended for another six months. The court may also create a creditors committee representing different classes of creditors. This committee may advise and supervise the activities of the commissioner; it can also request the replacement of the commissioner from the court ${ }^{43}$.

\section{B. Stay Period (Moratorium) and Ballot}

The stay period protects the debtor from the ongoing and future compulsory enforcement procedures. However, first rank priority credits stated in article 206 of the CCEB (select labor credits, alimony and child support payments) are exempt from this stay (art. 294). Credits secured by property may also be pursued however the property in question cannot be granted protection or sold

\footnotetext{
40 p. 24, https://www2.tbmm.gov.tr/d26/1/1-0913.pdf, (Last accessed: 14.06.2020); Also see AYER / BERNSTEIN / FRIEDLAND.

41 TUNÇ YÜCEL, p. 2; SARISÖZEN, p. 81.

42 KALE, p. 229.

43 BÖRÜ, pp. 363-366.
} 
(art. 295). The debtor, in principle, stays in possession ${ }^{44}$ and in control during this period. All her activities must be carried out under the supervision of the commissioner; the court even has the power to put the commissioner in charge instead of the debtor (art. 297/I). The debtor is also prohibited from certain activities such as pledging properties or signing surety agreements (art. 297/ II).

The commissioner informs all creditors on the meeting for the ballot after inviting them to claim any credits that were not identified by the debtor. The minimum approval requirements for concordat are determined by the CCEB based on two probabilities (art. 302). The proposal must be approved by:

- Half of the creditors and the creditors representing half of the total amount of credit or,

- A quarter of the creditors and the creditors representing two thirds of the total amount of credit.

These numbers relate to uncontested credits. If a credit is contested, the eligibility of the creditor to vote is dependent on the court's decision. Only the creditors affected by the project (and also who are not relatives of the debtor) are allowed to vote. If a creditor gives dissenting vote to the project, she retains all the legal rights against any guarantors regarding the credit (art. $303)$.

\section{Confirmation, Discharge and Revocation}

After the ballot is completed favorably, the commissioner presents the case file and her report to the court. The court, after hearing the objecting parties, decides on the confirmation request. Conditions for confirmation are specified by the CCEB (art. 305). In order for the court to confirm a concordat, the court must determine that:

(1) Proposed amount to be paid to the creditors is higher than the amount to be achieved by the bankruptcy (liquidation) of the debtor ${ }^{45}$;

44 It must be noted that, this is not the technical concept of "debtor in possession" as in Chapter 11 proceedings. That concept does not exist in Turkish reorganization schemes. See also POSTACIOĞLU, p. 11; ULUÇ / SUTTON / YAVASI, p. 103.

45 Similar: Directive (EU) 2019/1023 of the European Parliament and of the Council of 20 June 2019 on preventive restructuring frameworks, on discharge of debt and disqualifications, and on measures to increase the efficiency of procedures concerning restructuring, insolvency and discharge of debt, and amending Directive (EU) 2017/1132 (Directive on restructuring 
(2) Proposed amount is proportional to the assets of the debtor;

(3) Project is approved by the required number of creditors;

(4) Security is given for the priority creditors and for credits duly created during the stay period;

(5) All expenses and government duties are paid.

A notable absence from the conditions stipulated by the Statute is the good faith of the debtor. Before the 4949 reform, one of the conditions set by the Code for confirmation of concordat was the good faith of the debtor. However in order for the procedure to be more objectively carried out, said condition was removed from the $\operatorname{Code}^{46}$. Since then, it is debated that whether the debtor is obliged to possess good faith in the process ${ }^{47}$. Even though good faith is not listed as a condition for confirmation, the provision in article 308/f stipulates that any creditor may request the revocation of concordat claiming that the concordat was invalidated due to bad faith of the debtor. In that case, if the court grants the request, the concordat is revoked as a whole and if the debtor is eligible for bankruptcy and grounds for direct bankruptcy is present, the court renders judgment for bankruptcy (art. 308). This sanction is also applicable to the rejection of confirmation by the court ${ }^{48}$.

The decision regarding the confirmation or rejection of concordat is appealable by the debtor or the creditors (art. 308/a). After the intermediate appeal, the decision may also be contested in the Court of Cassation. This possibility is limited to this occasion however, the decisions regarding stay period are mostly final ${ }^{49}$. If concordat is confirmed by the court, the concordat project and its conditions become binding for all creditors affected by the

and insolvency) art. 2/1/6: "best-interest-of-creditors test" means a test that is satisfied if no dissenting creditor would be worse off under a restructuring plan than such a creditor would be if the normal ranking of liquidation priorities under national law were applied, either in the event of liquidation, whether piecemeal or by sale as a going concern, or in the event of the next-best-alternative scenario if the restructuring plan were not confirmed. (https://eurlex.europa.eu/eli/dir/2019/1023/oj Last Accessed: 22.06.2020).

46 Preamble of the Statute numbered 4949, p. 16, https://www2.tbmm.gov.tr/d22/1/1-0550.pdf (Last accessed: 24.06.2020); See also TAŞPINAR AYVAZ, p. 241.

47 TAŞPINAR AYVAZ, p. 241; TANRIVER (4949), pp. 67-90; PEKCANITEZ / ERDÖNMEZ, p. 130-131; See also TANRIVER / DEYNEKLI, pp. 77-86.

48 KALE, p. 254.

49 See TORAMAN, pp. 207-225. 
project. The concordat is compulsory for all credits before the concordat request and created during the period without the consent of the commissioner (art. 308/c). However, (1) first rank priority creditors stated in article 206 (select labor credits, alimony and child support payments), (2) credits secured by property (limited to the secured amount), and (3) public arrears ${ }^{50}$ (backtaxes etc.) are excluded from the compulsoriness of the scheme.

After the confirmation, if the debtor performs in accordance with the confirmed agreement, she is discharged from all her previous debts ${ }^{51}$. However, if she fails to make a payment, the unpaid creditor may request from the court a partial revocation (art. 308/e). Unlike the revocation as a whole that was mentioned above, partial revocation bears legal consequences only between the debtor and the requesting creditor. If the court grants partial revocation, the creditor becomes entitled to the previous (real) amount in case of an impaired claim. Furthermore, she retains any additional perks provided by the concordat.

\section{NEGOTIATION WITH SECURED CREDITORS AND STRUCTURING OF CREDITS}

As it was discussed above, the 2018 (7101) amendment, along with the aforementioned overhaul of the concordat procedure, has introduced an ancillary procedure to ordinary concordat called negotiation with secured creditors and structuring of credits. This procedure may be categorized as a completely new type of reorganization, if only it were not ancillary to ordinary concordat. (art. 308/h). This negotiation procedure involves creditors whose credits are secured with property (pledge or mortgage). Historically in Turkish law, these types of credits were always excluded from any type of reorganization procedure. This provision, which was added to the proposed bill in the Parliament, encourages the debtor to negotiate with said secured creditors $^{52}$. Negotiations and indeed settlements between the debtor and secured creditors were always possible as we have explained above. However, this provision also provides a mandatory aspect to such negotiations and agreements for other secured creditors. If the debtor successfully negotiates with any of her secured creditors representing more than two thirds of her total

50 This exemption is justly criticized. (ATALAY, p. 132-133)

51 POSTACIOĞLU, p. 12; BERKIN, p. 348.

52 In the original bill, secured creditors were to be included in the ordinary concordat procedure albeit in a class of their own. (ATALAY, p. 131) 
amount of secured debts, other creditors who have not reached an agreement with the debtor are also affected from this procedure. The provision stipulates that, (1) if an agreement is reached between the debtor and her creditors representing two thirds of the total secured debt, and (2) the main ordinary concordat proposal was also successful, than an agreement between the debtor and other secured creditors is assumed to be reached. The result of this is that, the dissented secured creditors' credits are to be paid with the interest rate before the debtor's default and the new due date will be determined in accordance with the agreement between the debtor and any secured creditor that grants the latest due date. Therefore, the dissenting creditor is going to be bound by the continuance and the reduced interest rate. Since this provision cannot completely devoid the secured creditors of their property rights protected by the substantive law, even if the debtor had made an agreement with any secured creditor reducing the credit, this reduction cannot be imposed on the dissenting creditor; i.e. the credit of the dissenting creditor cannot be impaired. However, even though this is true for the principle credit, it is false for the interest, since the interest rate rolls back to pre-default rate; which will most likely be a reduced rate ${ }^{53}$. This provision is justly criticized in literature ${ }^{54}$.

Principle problematic aspect of the procedure is the absence of the equality principle within the class. As we have explained above, any concordat (composition) agreement must be equal for the creditors (within the class). However, since the art. $308 / \mathrm{h}$ provision authorizes the debtor to make separate agreements with particular secured creditors; it represents a severe deviation from the basic equality principle ${ }^{55}$.

In addition, the Legislator seems to have carefully avoided using the title concordat for this procedure. The article even includes a provision stating that none of the concordat provisions in the Code (art. 285-309/1) are to be implemented for this procedure. However, even though the title suggests a "negotiation", the compulsoriness of the scheme is unmistakable. The ADR aspect of this procedure will be discussed in the following chapter.

One last thing to note regarding negotiation with secured creditors and structuring of credits is that this scheme is not a freestanding one; it must

53 SARISÖZEN, p. 210.

54 PEKCANITEZ / ERDÖNMEZ, pp. 112-117; SARISÖZEN, pp. 206-213; BUDAK (ÖztekKonkordato Şerhi), m. 308/h.

55 PEKCANITEZ / ERDÖNMEZ, pp. 184. 
be carried out ancillary to an ordinary concordat procedure. As the provision stipulates, this scheme can be confirmed by the court only if the main ordinary concordat is confirmed. Therefore, if the unsecured creditors do not approve the (main) concordat plan, the article $308 / \mathrm{h}$ procedure cannot be mandatory. However, if the article $308 / \mathrm{h}$ procedure fails, main concordat is unaffected from this; since this is an ancillary scheme.

\section{CONCORDAT IN BANKRUPTCY}

Concordat in bankruptcy is very similar to the ordinary concordat in many aspects. As the name suggest, the aim of this type of concordat is not the prevention of bankruptcy but to deliver the debtor out of bankruptcy. If the debtor whose assets are being liquidated within a bankruptcy process presents a concordat proposal and it is accepted by the creditors and confirmed by the court, the bankruptcy status gets removed by the court (art. 309). Since liquidation is already under way, there is already a stay/moratorium in this type of concordat. In addition, the board of trustees operating in the liquidation assumes the duty of the (concordat) commissioner; therefore a separate commissioner is not appointed by the court. The conditions for approval and confirmation as well as the admissible contents of the proposal are identical to the ordinary concordat. The Code limits the application for this type of concordat within a liquidation procedure to a single time; i.e. if the proposal fails, the debtor cannot apply with a second proposal (art. 309).

\section{CONCORDAT BY WAY OF CESSION OF ASSETS}

As we have discussed above, concordat by way of cession of assets was introduced in 2003 with the 4949 reform. This type of reorganization combines various aspects of ordinary concordat and bankruptcy liquidation. Even though it is proposed, approved and confirmed in a similar fashion to concordat, the end result is the liquidation of the debtor's assets. Unfortunately, the practice of concordat by way of cession of assets is almost non-existent in Turkey ${ }^{56}$.

The proposal must contain the particulars of the liquidation. It must state how the assets will be handled, transferred or sold, whether the creditors have waived from the remainder of their credits, how the liquidation officers and the creditors committee will be formed and other points determined by the Code (art. 309/b).

$56 \quad$ YILMAZ, p. 1283. 
After the confirmation of the concordat becomes final (i.e. all appellate remedies are exhausted), the power of disposition over the debtor's assets (not the assets themselves) are transferred to the creditors, or the assets are transferred to third parties and the profits go directly to the creditors (art. $309 / \mathrm{c}$ ). The assets of the debtor form an estate, and this estate is represented by the liquidation officers (and the creditors committee). Even though concordat by way of cession of assets resembles the bankruptcy liquidation, the former is much more flexible and efficient, since necessary rulings are made directly by the creditors committee and executed by the liquidation officers ${ }^{57}$.

Similar to the bankruptcy liquidation, after the credit claims are accepted and the liquidation of the estate is finished, liquidation officers draft a payment schedule and distribute the proceeds to the creditors accordingly. The major difference here is that, unlike bankruptcy, insolvency certificate is not issued to any unpaid (impaired) creditors ${ }^{58}$. Therefore, at the end of the proceeding, at least in principle, the debtor is discharged from her unpaid debts, as this is the case with the other types of concordat.

\section{RESTRUCTURING OF CORPORATIONS AND COOPERATIVES VIA RECONCILIATION}

\section{A. Requirements for Restructuring}

Restructuring of corporations and cooperatives via reconciliation represents the more professional aspect of reorganization in Turkish insolvency law. Unlike concordat which is available to any debtor; restructuring, as the name suggest, is available only to corporations and cooperatives. It is also more complicated than simple concordat since the debt-credit relations involved in this procedure are usually more complicated as well. Unlike the previously examined reorganization procedures, reconstruction involves a reorganization of the corporation itself, along with the reorganization of the debts ${ }^{59}$. It must be noted however, as it is the case with concordat by way of cession of assets, reconstruction by reconciliation is unfortunately is a rarely utilized way of reorganization ${ }^{60}$.

\footnotetext{
57 ATALI / ERMENEK / ERDOĞAN, p. 714.

58 Ibid.

59 TAŞPINAR AYVAZ, p. 291; YARICI, pp. 20-25.

60 YILMAZ, p. 1297; ATALI / ERMENEK / ERDOĞAN, p. 719.
} 
In order for a debtor to apply for this type of reorganization, it must be a joint stock company, a limited liability company, a commandite company limited by shares, or a cooperative. Banks and insurance companies are barred from applying for restructuring as debtors (art. 309/t). Being in financial trouble constitutes sufficient grounds for application; the company could be over-indebted, insolvent or even carry a probable risk for either ${ }^{61}$. The application is made to the commercial court with a detailed restructuring project. The expected contents of the project are determined by the Code (art. 309/n). The project must include:

(1) Conditions to be applied to creditors affected by the project and how equality is going to be ensured between similar creditors;

(2) Possible effects of the project to contracts which the debtor is a party to;

(3) Effects of the project to the debtor's power of disposition on its assets;

(4) Whether the debtor is going to resort to financial resources such as loan should it is deemed necessary;

(5) Methods to ensure feasibility of the project such as transfer of the business, mergers, amendments to charter, assignment of management of the business, continuance for debts, modification of interest rates, issuance of securities;

(6) Who will audit the implementation of the project after confirmation;

(7) Acknowledgment that the dissenting creditor will be treated equally with similar creditors, unless said creditor had expressly accepted less than what is provided for her class.

\section{B. Stay, Approval and Confirmation of the Project, Revocation}

Along with the project, the debtor must also present any relevant documents such as financial statements, list of creditors etc. to the court. The debtor must also provide the notarized records for the approval process of the project (art. 309/o). The complete negotiation and approval (ballot) processes in restructuring occur prior to the application to the court. Therefore, no stay/ moratorium is available for the debtor before the project is presented to the court. Unlike concordat, the debtor, in restructuring, may create classes,

${ }^{61}$ TAŞPINAR AYVAZ, pp. 297-301. 
provided that similar credits are placed in the same class ${ }^{62}$. A creditor, due to her various credits from the debtor may be placed in multiple classes ${ }^{63}$. When this is the case, said creditor casts a vote for each class that she is, resulting in multiple votes ${ }^{64}$. Each class member must be treated equally ${ }^{65}$. Unlike concordat, the debtor may also designate credits that are to be excluded from reconstruction ${ }^{66}$. Creditors of such credits are not allowed to vote. Since the voting process is carried out outside the court, it must be conducted professionally and in accordance with the Restructuring of Corporations and Cooperatives via Reconciliation Regulation (RCCRR) issued by the Ministry of Justice in 2004. Each class must approve the project with simple majority with respect to creditors and at least two thirds with respect to the total amount of credit within the class. If multiple classes are designated, said majority must be satisfied by all classes. As we will explain in the following chapter, there is no cram down power; the project cannot be confirmed if a class does not approve the project (art. 309/m/IV).

After the debtor applies to the commercial court and presents the project and other required documents as stated above, the court commences the proceedings. Upon the request of the debtor or any creditor, the court may issue injunctions or any other provisional remedies. This power includes the stay of any compulsory enforcement procedures against the debtor, limited to creditors affected from the project (art. 309/ö). The court may also appoint an interim auditor to either directly assume control of the operations of the debtor or to audit said operations until the confirmation or rejection of the project. This auditor may be elected by the debtor and the creditors.

The court examines the application thoroughly and in order for it to confirm the project, it must determine that (1) the debtor is acting in good faith, (2) all requirements set by the Code are met, and (3) the amount to be received by dissenting creditors matches the amount to be procured by bankruptcy liquidation (art. 309/p). Otherwise, it rejects the project. Upon rejection, all injunctions and provisional remedies imposed by the court (such as

\footnotetext{
$62 \quad$ Ibid, p. 308.

63 Ibid, pp. 313-314; PEKCANITEZ / ATALAY / SUNGURTEKIN ÖZKAN / ÖZEKES, p. 840; Restructuring of Corporations and Cooperatives via Reconciliation Regulation, art. 6.

64 TAŞPINAR AYVAZ, p. 332.

65 YARICI, p. 57.

66 Ibid, p. 303.
} 
moratorium) are automatically vacated (art. 309/r). If the project is confirmed, the court also appoints one or multiple auditors to audit the application of the project. Upon the confirmation judgment, the project commences. The conditions of the project supersede any and all agreements between the debtor and the affected creditors.

Should the debtor perform the conditions of the project accordingly; it is discharged from its debts created before the confirmation. However, if it fails to do so, similar to concordat, restructuring may be revoked by the court upon identical grounds (art. 309/s). The project may also be partially amended involving a creditor if needed by the court's permission (art. 309/ş). If the debtor breaches the conditions of the project, the court is informed by the auditor or the creditors. If the court determines that the project could not be salvaged or the financial creditor is not paid, it renders a judgment for bankruptcy (art. 309/t).

\section{CHAPTER III: THE ADR PERSPECTIVE}

\section{ALTERNATIVE DISPUTE RESOLUTION IN GENERAL}

Alternative dispute resolution or ADR in short, refers to a range of mostly out-of-court and voluntary dispute resolution procedures between dissenting parties, usually involving an independent and neutral third party whose role is to lead the parties to reconciliation and ultimately settlement ${ }^{67}$. This definition however may be somewhat restricting, since there are many types of ADR methods utilizing various techniques for dispute resolution. Most common ADR methods throughout the world are negotiation, mediation and conciliation. Whether arbitration is a type of ADR is a matter of dispute, however examination of this dispute exceeds the confines of this article ${ }^{68}$.

ADR is a concept that is dependent on the concept of dispute; meanwhile dispute is a concept that is based on the concept of conflict ${ }^{69}$. When or if a conflict between parties is turned into conflict, it is ought to be resolved. Traditional dispute resolution sits with the state. One of the principle duties of the state is to enforce its subjects' rights should they need enforcement ${ }^{70}$. If a

\footnotetext{
67 ÖZBEK, pp. 167-168; ILDIR, p. 26; GÖKSU (ADR), p. 18; KERLEY / BANKER HAMES / SUKYS, p. 11; JAMES / HAZARD / LEUBSDORF, p. 349.

68 See EKMEKÇI / ÖZEKES / ATALI / SEVEN, pp. 10-12.

69 ÖZBEK, p. $99 \mathrm{ff}$.

70 KURU, p. 48. Also the Constitution, art. 36 (Freedom of Claiming Rights).
} 
subject fails to deliver the right of another subject, the state intervenes with the request of the aggrieved party. Even though this duty of the state is constant, parties may want to and are increasingly willing to resolve their disputes through more amicable means. ADR provides tools for reconciliation, rather than judgments ${ }^{71}$.

Alternative dispute resolution may be seen as "dispute resolution" in itself or a tool in pursuit of settlement. In Turkish law, it is mostly the former. Settlement or sulh in Turkish refers to parties' agreement on ending a dispute with mutual concessions ${ }^{72}$. The term sulh literally means peace. Settlement finds its place in the Code of Civil Procedure. Settlement terminates the court action as well as the right of claims of the parties regarding that action ${ }^{73}$. However, this is the case for an in-court settlement. Out-of-court settlements are excluded from this rule. Out-of-court settlements refer to law of obligations agreements between parties; these types of agreements are not designated by the Turkish Code of Obligations ${ }^{74}$. However they are known and utilized, even if rarely. Major Turkish ADR methods on the other hand, which are mediation and conciliation, deliver their own comprehensive legal results apart from settlement. Both the Law on Mediation in Civil Disputes and the Law of Lawyers, designate the legal characteristics of the "record of agreement" according to their respective procedures. Therefore, neither of the major ADR methods utilized in Turkey leads the parties to a sulh, but to a propriety record of agreement, that is accepted as an enforceable document by the law. The parties however, at least in principle, can transform this agreement to an incourt settlement, should they wish so.

The Turkish viewpoint of dispute resolution contains another important aspect, which is the distinction between a legal dispute and a monetary claim. Mostly due to the fact that Turkish law implements debt enforcement procedures regarding monetary claims without the need for a court judgment ${ }^{75}$, Turkish civil procedural law and Turkish compulsory enforcement law are deemed

71 JAMES / HAZARD / LEUBSDORF, p. 344; ÖZBEK, pp. 173-174.

72 ARSLAN / YILMAZ / TAŞPINAR- AYVAZ / HANAĞASI (Usul), p. 566; TANRIVER (Usul), p. 1022. Also the Code of Civil Procedure art. 313.

73 ARSLAN / YILMAZ / TAŞPINAR- AYVAZ / HANAĞASI (Usul), pp. 566-567; TANRIVER (Usul), p. 1030. Also the Code of Civil Procedure art. 315.

74 KILINÇ, p. 510.

75 For claims other than money, the creditor must file an action and secure an enforceable judgment. (GÖKSU (Recovery), p. 4) 
distinct yet tightly connected legal disciplines. Most of the proceedings in debt enforcement procedures, even the ones that involve compulsory enforcement courts, do not ultimately resolve disputes between the debtor and the creditor; they rather advance the enforcement proceedings ${ }^{76}$. Namely, the procedure itself does not result in res judicata. Only if a court other than compulsory enforcement court gets involved in the process and said court resolves the disputes in accordance with general rules and provisions, then it becomes a dispute resolution in the real sense, or at least in the Turkish jurists' eyes.

This distinction is also evident in mandatory (compulsory) mediation provisions: In Turkish law, barring some exceptions, labor disputes, commercial disputes involving a monetary claim and consumer disputes must be mediated before litigation ${ }^{77}$. The proper term for this burden is called mediation as procedural requirement. If the creditor (or the debtor in some instances) files an action to resolve a dispute that is subject to mandatory mediation without trying mediation beforehand, the court dismisses the case on procedural grounds. However, this rule only applies to filing an action (i.e. "real" dispute resolution), but not applying for debt enforcement without a judgment ${ }^{78}$. If the claim is monetary, the creditor may claim the credit via the enforcement procedure; she may even request the removal of objection in the compulsory enforcement court if the debtor had objected to the claim; the creditor is not obliged to mediate the dispute, since said procedure is not a real lawsuit ${ }^{79}$. This freedom solely relies on the fact that enforcement procedures without a judgment are not deemed real dispute resolution, as they lack res judicata as we have explained above. These points must be established and noted beforehand, since they will be crucial in our evaluation of reorganization.

\section{ARE ENFORCABLE CREDIT CLAIMS DISPUTES?}

The answer to this question is heavily dependent on the type of enforcement, which the enforceable credit claim is subject to. If one is talking about partial (or individual) debt enforcement, the answer should be "it usually is". The affirmative answer is mostly encountered within the enforcement without a judgment. If the debtor objects to the proceeding, which it is usually

\footnotetext{
76 KURU, p. 66; PEKCANITEZ / ATALAY / SUNGURTEKIN ÖZKAN / ÖZEKES, p. 117.

77 See GÖKSU (ADR), p. $73 \mathrm{ff}$.

78 EKMEKÇI / ÖZEKES / ATALI / SEVEN, p. 195; ERMENEK / AZAKLI ARSLAN, p. 149, 155.

79 ARSLAN / YILMAZ / TAŞPINAR-AYVAZ / HANAĞGSI, p. 186.
} 
the case, it is evident that there is not just a conflict but also a dispute between the parties. Even if the debtor abstains from objecting to the proceeding; since the proceeding does not constitute res judicata on its own as we have stated above, she may file an action for restitution against the creditor at a later date ${ }^{80}$. In regular enforcement procedures (i.e. enforcement based on judgment) however, disputes are rare. Since a court had already removed the dispute with a (final) judgment, disputes in this case generally arise from ancillary matters such as the statute of limitations for the judgment. If there is a dispute between the parties, than a dispute resolution should of course be carried out. However, if there is no dispute between the parties, for example if a judgment on the matter exists, yet the debtor simply failed to pay; now the question is whether this claim is a dispute. Then the answer is "no". This, at least in Turkish law, cannot be conceived as dispute, but a conflict. Therefore, a conflict resolution may become necessary, but not dispute resolution. This probability (conflict resolution) is addressed in the CCEB. The Code allows for the parties to make agreements (e.g. continuance for payment) before the enforcement agency and determines the outcomes of such agreements ${ }^{81}$. Therefore, even during an individual enforcement, amicable conflict resolution is probable and even encouraged.

Similar arguments may also be made regarding insolvency, or collective enforcement as it is called in Turkish law. The major difference between individual and collective enforcement with regard to our current subject, is mostly the probable lack of a claim in the latter. Since all individual enforcement procedures begin with a claim; a dispute or at least a conflict is always present. However, in collateral enforcement, a creditor whose credit is not even yet overdue may (and should) become involved due to the collectiveness of the procedure. On the other hand, a creditor may have initiated the insolvency proceedings; or the claim brought forward by the creditor may be rejected by the debtor. Therefore, it depends on the matter at hand. On some occasions, a complete absence of dispute is also possible in insolvency proceedings: The debtor may have accepted all her debts but simply failed to pay them. If the credit claimed by the creditor is contested by the debtor or the officer(s) carrying out the procedure (e.g. liquidation officer, board of trustees etc.); or even another creditor, than a dispute is deemed existent and it must be resolved.

\footnotetext{
80 GÖKSU (Recovery), p. 13.

81 ATALI / ERMENEK / ERDOĞAN, p. 276 ff.
} 
If there is no such dispute or they are resolved by any means, then the amount to be paid as the result of the proceedings becomes the primary issue. If the procedure is bankruptcy liquidation, the creditors are paid in accordance with rules and regulations and they make do with what they procure. However, if the procedure at hand is a type of reorganization, the procedure itself becomes a matter of contention. If the debtor accepts all credit claims however lacks the means to pay them and resorts to concordat or Chapter 11 bankruptcy or voluntary agreement or any other similar procedure; is there a dispute between the debtor and her creditors? This is the major question to be answered. Simple answer to this question is "yes"; because the legal matter at hand now differs from the credit relation between the creditor and the debtor. Even if the amount or type of credit is undisputed, the aspiration of the debtor to pay less or secure a continuance points to a conflict. When said debtor concretizes this aspiration and applies for a reorganization scheme, said conflict transforms into a dispute. And as it is the case with all disputes, this dispute must be resolved. Dispute may also be existent in the matter of involuntary petition, i.e. the request of a creditor for reorganization. Almost all reorganization schemes present this opportunity to creditors yet it is hardly ever encountered. It is more probable and prevalent in liquidation bankruptcy, at least in Turkish bankruptcy law.

\section{REORGANIZATION SCHEMES AS TOOLS FOR NEGOTIATION}

Apart from the outlying examples such as the now defunct postponement of bankruptcy, the resolution of all reorganization schemes are two-stage affairs: Approval and confirmation. While the first stage is carried out with the direct involvement of the creditors; second and final stage is within court's jurisdiction. The governance of both stages, especially the second stage may vary according to the type of reorganization. Courts sometimes have vast power of discretion on some matters, while almost none on others. Nevertheless, it should always be within the court's jurisdiction to confirm a reorganization scheme as it becomes mandatory for the dissenting creditors. This compulsoriness aspect can only be reached with the involvement of a court; it cannot be the achieved nor should it be forced by an administrative order or a type of alternative dispute resolution.

The matter that we should deliberate is then, is the first stage of the reorganization scheme. As we have stated above, almost all reorganization schemes, historically beginning with concordat, must involve the approval 
of a number (usually majority) of creditors ${ }^{82}$. One can easily say that, this approval requirement constitutes the sine qua non aspect of any reorganization scheme $^{83}$. This conclusion demonstrates the bridge between insolvency reorganization and amicable dispute resolution.

Since this article is limited to Turkish insolvency law, we will focus on concordat and restructuring of corporations and cooperatives via reconciliation schemes. All procedures under the reorganization umbrella in Turkish law, as we have examined above, are comprised of two stages. The differences between schemes are limited to details.

Both ordinary concordat and concordat by way of cession of assets starts with an application to the court. After the stay period is commenced and necessary steps are taken (e.g. preparation of list of claims), the democratic aspect of the schemes steps in. The creditors are summoned to meet and vote on the project drafted by the debtor. The project is fixed here and the only thing that takes place is the ballot with no signs of a real negotiation ${ }^{84}$. Even the Code fails to make any referrals to a negotiation between the debtor and the creditors. Such negotiation may of course and should be carried out before the finalization of the project and thus the ballot; even though this matter is completely ignored by the Code. If the creditors approve the project with the majority required by the Code, than the first stage gets completed and the court acts for the second stage (i.e. confirmation). If the approval fails, than the need for the second stage is negated since the court lacks the power to confirm a reorganization scheme on its own. Therefore this means the end of the line for the concordat project.

The recently established ancillary procedure to ordinary concordat, namely the negotiation with secured creditors and structuring of debts on the other hand, is completely different with regard to the negotiation concept. Since even the name includes negotiation, it is a very important aspect of the procedure. Unlike other reorganization schemes, all negotiations and agreements made by the parties are carried out individually in the article

82 CONWAY, p. 8; EISENBERG, p. 553 ff; VÉLYVIS / MIKUCKIENĖP, p. 294.

83 The preamble of the Statute numbered 7101which repealed postponement of bankruptcy mentions the lack of creditors' input as a reason for the failure of the procedure and promotes negotiation and agreement between the debtor and the creditors as better tools for replacement. (p. 19, https://www2.tbmm.gov.tr/d26/1/1-0913.pdf - Last accessed: 24.06.2020)

84 PEKCANITEZ / ERDÖNMEZ, p. 109. 
$308 / \mathrm{h}$ scheme. This individuality is of course not mandatory, the debtor may submit same terms and conditions to all her secured creditors and enter into the same agreement with them. This freedom on individuality brings forward the infringement of the equality within the class rule by the hands of the Code $^{85}$. This means that the debtor can submit more favorable proposals to her bigger secured creditors and thereby bypass smaller secured creditors. Another critical point in this procedure is that, majority rule is limited to only the amount of credit but not the creditor count. Therefore, for instance if the debtor has a major secured creditor such as a bank who owns at least the two thirds of all her secured debts and an agreement is reached between the two, said agreement, save for any monetary reduction, becomes compulsory for all other dissenting secured creditors after the court's confirmation of ordinary concordat as a whole. Furthermore, the dissenting creditor is deprived of any favorable interest terms on the aforementioned agreement, since the interest rate is stipulated by the Code in this case. Even though the name of the scheme suggests negotiation, one must say that, the lack of protection for dissenting secured creditors in the article $308 / \mathrm{h}$ procedure is alarming and far removed from the concept of amicable resolution. One may even say that the Legislator, with this provision, aims to compel secured creditors to negotiate and agree with the debtor in order for them to fend off any unwanted outcome from the compulsoriness of the procedure. Whether this is a positive or a negative approach in the encouragement of amicable resolution is up to the Reader.

Restructuring on the other hand, works differently with respect to approval. Since the ballot stage is carried out before the application to the court and the stay period, unlike concordat, negotiation is more probable. Even the Code and article 5 of the Regulation (RCCRR) mention the phrase "negotiation with creditors". The Code stipulates that the debtor must carry out negotiations with creditors and also summarize said negotiations in the application to the court. But there are no provisions in the Code or the Regulation on how to carry out said negotiations. There are no limitations for such negotiations; it is left mostly up to the debtor ${ }^{86}$. According to the Code, the ballot stage comes after said negotiations. Therefore a negotiation after the commencement of the ballot stage seems, at least in principle, not possible. Similar to concordat, an approval must be given by the creditors with sufficient majority. The court process begins after the negotiation phase and the ballot. Once again, similar

\footnotetext{
85 PEKCANITEZ / ERDÖNMEZ, pp. 113-114.

86 TAŞPINAR AYVAZ, p. 325
} 
to concordat, the court cannot confirm a restructuring without the approval of the creditors. The difference here is that, unlike concordat, the debtor pursuing a restructuring may create creditor classes. Each of these classes must approve the proposal. Unlike Chapter 11 or similar reorganization schemes, there is no cram down power in Turkish restructuring provisions ${ }^{87}$. Therefore, if an entire class rejects the proposal, the project cannot be confirmed under the cram down rule; the approval is required as a whole (art. 309/m). The lack of cram down power may be seen, at least in the practical sense, acting in the service of amicable resolution and forces parties to a more encompassing agreement.

\section{COMPULSORINESS OF REORGANIZATION SCHEMES (AND CRAM DOWN POWER)}

As it is summarized above, all reorganization schemes in Turkish law are subject to creditors' approval. However, the key point is that, approval here is not an express individual approval, but an assumption of approval on the basis of majority. In order for an alternative dispute resolution method to be successful and a settlement (or agreement) is to be achieved, as it is the case in all contracts, a mutual assent between the parties is needed ${ }^{88}$. The major characteristic of ADR procedures is voluntariness ${ }^{89}$. Even in instances such as mandatory (compulsory) mediation, the imperativeness manifests itself in the commencement phase, not the end result. The parties may be obliged to refer to mediation or another ADR procedure by law or by contract; but they cannot be compelled to any solution on which they do not mutually agree. The compulsoriness of reorganization schemes for dissenting creditors clearly clashes with this principle notion. This is why these schemes are mostly considered as not settlements or agreements but collective compulsory enforcement instruments. However, if a debtor and the creditor mutually agree on a type of restructuring of the debt between the two, this is by all means amicable resolution. Furthermore, if the parties have reached to this agreement as the result of negotiation or a process like mediation or conciliation, ADR should duly be credited. These agreements may also be enforced, should they possess necessary requirements imposed by the law (such as mediation agreements, in-court settlements or agreements before compulsory enforcement agencies).

87 Ibid, 395-396.

88 REISOĞLU, p. 51; EREN, p. 284; KERLEY / BANKER HAMES / SUKYS, p. 399; ÖNEN, p. 23.

89 ÖZBEK, p. 277; GÖKSU (ADR), p. 21. 
The main question then concentrates on the function of reorganization schemes. If the debtor and the creditors have negotiated and a majority of the creditors approved the scheme, can this be considered a settlement? The answer should be "no". Settlement, as we have previously explained is a contract; and similar to all other contracts, a mutual assent between the parties must be present ${ }^{90}$. If a person is forcibly included in a "settlement", it cannot be called as such by definition, since it lacks the fundamental core of the concept of settlement. Therefore any reorganization schemes, be it concordat or restructuring, are defined as compulsory enforcement instruments. They draw their power from the power of the State and could not be enforceable without such power. The major infringers here are the compulsoriness of the procedure and the cram down power. As we have mentioned before, there is no cram down power in any reorganization scheme in Turkish law. The compulsoriness, on the other hand, constitutes the key aspect of all reorganization procedures. However, it must be noted that, the compulsoriness itself is also dependant on the approval of the majority of the creditors. There may not be a complete approval from the creditors as in settlement, but at least major approval exists among the creditors. Therefore, the amicable resolution aspect of the topic could not be overlooked. Furthermore, even if the end result may not be treated as settlement, the process itself is a completely different subject. There is no hindrance, at least in the mind of the writer of this article, for treating reorganization procedures as sort of amicable conflict resolution, if not full-fledged alternative dispute resolution. It is a fact that these schemes encourage the creditors to negotiate with the debtor and vice versa. This encouragement may best be seen with regard to the negotiation with secured creditors and structuring of debts procedure in Turkish law.

Another aspect of the reorganization schemes to be examined on the matter is the time and extent of the compulsoriness, i.e. is the creditor bound by the approval or agreement even if the concordat or restructuring fails? The answer once again must be negative. As we have explained above, these agreements by themselves cannot be regarded as real agreements. Instead, they are merely prerequisites for concordat or restructuring to be confirmed by the court. No concordat or restructuring project may commence and generate its legal results before confirmation. Therefore, even if a creditor agrees to the project, her credit gets impaired only after the confirmation; her declaration of intention cannot be regarded as an acceptance of settlement or waiver. This

90 KERLEY, / BANKER HAMES, / SUKYS, p. 399; ÖNEN, p. 23. 
concept is also very similar to its counterpart in ADR negotiations ${ }^{91}$. This nonbinding aspect of the reorganization schemes is very similar to the non-binding proposals and acknowledgments made by the parties in ADR procedures; unless an agreement is signed, none of these proposals or acknowledgments become binding ${ }^{92}$. This conclusion is also evident in the revocation of concordat or restructuring by the court. In such case, even if the creditor has agreed to the project, she can claim the entirety of her once impaired claim. This conclusion however, may be circumvented by the parties, if they have negotiated a real settlement agreement or another agreement such as the one before a mediator.

\section{CONCLUSION}

Reorganization schemes in insolvency law are indispensible contemporary tools that are ever evolving and adapting to any jurisdiction in which they are utilized. From the relatively small reorganization of a small debtor, to the restructuring of a billion-dollar corporation, these mechanisms not only rescue and relieve the persons under financial distress, but also deliver results in the macroeconomic scale. The variety and diverseness of reorganization schemes are necessary as needs tend to change from debtor to debtor and legal system to legal system. This diverseness ensures availability of the most relevant measures and reliefs not only to debtors, but also the creditors. In Turkish law, concordat procedures representing the more general side and corporation restructuring proceedings representing the more professional side of reorganization, present strong sustaining alternatives to the bankruptcy that is opposite in nature.

It must be outright admitted that, as the origins and historical roots of reorganization and restructuring schemes suggest, the aim of these schemes are not, at least directly, the amicable resolution between the debtor and the creditors. Whether this aim is the protection of the debtor from ruin or the rescue of financially distressed companies, the amicable resolution aspect appears to be a by-product or even an instrument in achieving said aims. However, it must be noted that, even if an institution is established with a particular purpose in mind, it doesn't mean that it cannot deliver for other needed purposes just as, if not even more, successfully.

\footnotetext{
91 ÖZBEK, p. 139. Also the Code of Civil Procedure art. 188/3; the Law on Mediation in Civil Disputes art. 5.

92 Ibid.
} 
As we have discussed above in detail, the amicable resolution aspect of reorganization mechanisms should not be overlooked and must be built upon. Reorganization mechanisms should be seen and treated as powerful and valuable tools in the pursuit of resolving conflicts and disputes in a more civilized and sustaining manner. Even if the final result that they produce is not settlement per se, as we have concluded, the process itself must be promoted and advocated as means of conflict or dispute resolution depending on the matters at hand. This promotion and advocacy should be carried out by the State and also the different players in the legal and financial communities in order for these mechanisms to pull away from their one-sided rescue tool image and accepted by the public as vehicles of understanding and peaceful resolution between the dissenting parties.

\section{BIBLIOGRAPHY}

ANSAY, S. Ş.: Hukuk İcra ve İflas Usulleri, $5^{\text {th }}$ Edition, İstiklal, Ankara, 1960.

ARSLAN, R. / YILMAZ, E. / TAŞPINAR- AYVAZ, S. / HANAĞASI, E.: İcra ve İflas Hukuku, $5^{\text {th }}$ Edition, Yetkin, Ankara, 2019.

ATALAY, O.: "Konkordato Reformu Hakkında Değerlendirmeler", 7101 Sayılı Kanunla Konkordato ve Elektronik Tebligat Konularında Getirilen Yenilikler, Oniki Levha, İstanbul, 2018, pp. 111-135.

ATALI, M. / ERMENEK, İ. / ERDOĞAN, E.: İcra ve İflas Hukuku, $2^{\text {nd }}$ Edition, Yetkin, Ankara, 2019.

AYER, J. D. / BERNSTEIN, M. / FRIEDLAND, J.: "Chapter 11-An Overview of the Automatic Stay", ABI Journal, Vol. XXII, No. 10, December/ January 2004.

AYHAN, R. / ÇAĞLAR, H. / ÖZDAMAR, M.: Şirketler Hukuku Genel Esaslar, Yetkin, Ankara, 2019.

BERKİN, N. M.: İflas Hukuku Dersleri, Hamle, İstanbul, 1960.

BÖRÜ, L.: "Adi Konkordatoda Alacaklılar Kurulu”, İnönü Üniversitesi Hukuk Fakültesi Dergisi, 9 (2), pp. 341-372. 
CONWAY, L.: Company Voluntary Arrangements, House of Commons Library Briefing Paper, No. 6944, 11 June 2019.

EISENBERG, T.: Bankruptcy and Debtor-Creditor Law, Fourth Edition, Foundation, New York, 2011.

EKMEKÇİ, Ö. / ÖZEKES, M. / ATALI, M. / SEVEN, V.: Hukuk Uyuşmazlıklarında Arabuluculuk, 2nd Edition, Oniki Levha, İstanbul, 2019.

EREN, F.: Borçlar Hukuku Genel Hükümler, Volume I, 5th Edition, Beta, İstanbul, 1994.

ERMENEK, İ. / AZAKLI ARSLAN, B.: "İcra ve İflâs Hukuku Açisindan Ticarî Davalarda Arabulucuya Başvuru Zorunluluğu (TTK m. 5/A)", TBB Journal 2020 (148), pp. 135-196.

ERMENEK, İ.: İflasın Ertelenmesi, 2 ${ }^{\text {nd }}$ Edition, Adalet, Ankara, 2010.

GÖKSU, M.: Alternatif Uyuşmazlık Yolları ve Tahkim, $2^{\text {nd }}$ Edition, Seçkin, Ankara, 2020. (ADR)

GÖKSU, M.: "Recovery of Monetary Credits by Way of Procedures for Compulsory Enforcement Without a Judgment According to Turkish Code of Compulsory Enforcement and Bankruptcy", Ankara Bar Review, Year 7, No 1, pp. 81-112. (Recovery)

GÜRDOĞAN, B.: İflas Hukuku Dersleri, Ajans-Türk, Ankara, 1966.

ILDIR, G.: Alternatif Uyuşmazlık Çözümü, Seçkin, Ankara, 2003.

JAMES, F. / HAZARD, G. C. / LEUBSDORF, J.: Civil Procedure, 5th Edition, Foundation, New York, 2001.

KALE, S.: “7101 Sayılı İcra ve İflas Kanununda Değişiklik Yapılmasına Dair Kanun Çerçevesinde İflas Dışı Adi Konkordato", İstanbul Medipol Üniversitesi Hukuk Fakültesi Dergisi 5 (1), Spring 2018, pp. 213-269.

KERlEY, P. / BANKER HAMES, J. / SUKYS, P. A.: Civil Litigation, 6th Edition, Delmar, New York, 2012.

KILINÇ, A.: "Mahkeme Dışında Yapılan Sulh ve Yargılamaya Etkisi", İstanbul Hukuk Mecmuası, 77 (2): 503-521.

KURU, B.: İcra ve İflas Hukuku El Kitabı, 2 ${ }^{\text {nd }}$ Edition, Adalet, Ankara, 2013. 
ÖNEN, E.: Medeni Yargılama Hukukunda Sulh, Ankara Üniversitesi Hukuk Fakültesi, Ankara, 1972.

ÖZBEK, M. S.: Alternatif Uyuşmazlık Çözümü, $3^{\text {rd }}$ Edition, Yetkin, Ankara, 2013.

ÖZTEK, S. / BUDAK, A. C. / TUNÇ YÜCEL, M. / KALE, S. / YEŞILIOVA, B.: Yeni Konkordato Hukuku, Adalet, Ankara, 2018. (Öztek-Konkordato Şerhi)

PEKCANITEZ, H. / ATALAY, O. / SUNGURTEKIN ÖZKAN, M. / ÖZEKES, M.: İcra ve Iflas Hukuku, $11^{\text {th }}$ Edition, Yetkin, Ankara, 2013.

PEKCANITEZ, H. / ERDÖNMEZ, G.: 7101 Sayılı Kanun Çerçevesinde Konkordato, Vedat, İstanbul, 2018.

POSTACIOĞLU, İ. E.: Konkordato, Banka ve Ticaret Hukuku Araştırma Enstitüsü, Ankara, 1965.

PULAŞLI, H.: Yeni Şirketler Hukuku Genel Esaslar, Adalet, Ankara, 2012.

REİSOĞLU, S.: Borçlar Hukuku Genel Hükümler, 14th Edition, Beta, İstanbul, 2000.

ROOME, J. / BANNISTER, T., / SIMMONDS, / T. PFLUEGER, T.: "Restructuring and insolvency in the UK (England \& Wales): overview, https://uk.practicallaw.thomsonreuters.com/ (Last accessed: 10.06.2020).

SARISÖZEN, S.: İcra-İflas ve Konkordato Hukukundaki Yenilikler, $2^{\text {nd }}$ Edition, Yetkin, Ankara, 2019.

TANRIVER S. / DEYNEKLİ, A.: Konkordatonun Tasdiki, Yetkin, Ankara, 1996.

TANRIVER, S.: “4949 Sayılı İcra ve İflas Kanunu’nda Değişiklik Yapılmasına Dair Kanun'un Adî Konkordato İle İlgili Hükümlerde Getirmiş Olduğu Değişikliklerin Tespiti Ve Değerlendirilmesi”, TBB Journal, No 51, 2004, pp. 67-90. (4949)

TANRIVER, S.: Konkordato Komiseri, Yetkin, Ankara, 1993. (Komiser)

TAŞPINAR AYVAZ, S.: İcra-İflas Hukukunda Yeniden Yapılandırma, Yetkin, Ankara, 2005.

TORAMAN, B.: “Konkordato Müessesesi Hakkında 7101 Sayılı Kanunla 
Getirilen Yeniliklerin Kanun Yollarına İlişkin Hükümleri Bakımından Değerlendirilmesi”, 7101 Sayılı Kanun Çerçevesinde Konkordato, Adalet Bakanlığ1, Ankara, 2019, pp. 207-225.

TUNÇ YÜCEL, M.: Konkordato Mühletinin Alacaklılar Bakımından Sonuçları, Oniki Levha, İstanbul, 2020.

ULUC, I. / SUTTON, K. R. / YAVASİ, M.: Bankruptcy in Turkey: a Comparative Study of Turkey's Adjournment of Bankruptcy and the United States' Chapter 11 Reorganization, Unıversity Of Bologna Law Review, Volume.3:1 2018, pp. 64-122.

UMAR, B.: İcra ve İflas Hukukunun Tarihi Gelişmesi ve Genel Teorisi, Ege Üniversitesi, İktisadi ve Ticari Bilimler Fakültesi Yayınları, İzmir, 1973.

UZAR, G.N.: İcra ve İflas Kanunu'nun Tarihsel Gelişimi, Unpublished Master's Thesis, Ankara, 2001.

UZAR SCHÜLlER, G.: "Chapter 42: Turkey", Collier International Business Insolvency Guide, Vol. 3 - Insolvency Laws of Selected Nations (Editors: R.F. Broude et al.), LexisNexis 2017.

ÜSTÜNDAĞ, S.: İcra ve İflas Kanunu'nun Dünü ve Bugünü, Evrim, İstanbul, 1990.

VĖLYVIS, S. / MIKUCKIENĖP, M.: "Origin Of Bankruptcy Procedure In Roman Law”, Jurisprudencija. 2009, 3(117), pp. 285-297.

WARREN, E.: "The Success of Chapter 11: A Challenge to the Critics", Michigan Law Review, Volume 107, Issue 4, 2009, pp. 603-640.

YARICI, H.: Sermaye Şirketleri ve Kooperatiflerin Uzlaşma Yoluyla Yeniden Yapılandırılması, Legal, İstanbul, 2007.

YEŞiLOVA, B.: Modern İflas Hukukunun Gereklilikleri ve Temel Haklar Çerçevesinde Susturma Hakkı / Engelleme Yasağı, Adalet, Ankara, 2015.

YILMAZ, E.: İcra ve İflas Kanunu Şerhi, Yetkin, Ankara, 2016. 
